\section{Move to overturn ban}

\section{Washington}

IN a move that is certain revive an old controversy, Representative Henry Waxman (Democrat, California) has introduced legislation to overturn the present moratorium on the use of US federal funds to support fetal tissue research. The two-year-old ban covers the transplantation of human fetal tissue from induced abortions into human recipients, but does not extend to the use of fetal tissue for transplantation into animals or for use in other more basic research studies. Despite the ban, privately funded clinical trials of fetal-tissue transplants are continuing in patients with Parkinson's disease and diabetes, and many scientists believe that patients with Alzheimer's disease, epilepsy, Huntington's disease, spinal cord injury and AIDS could benefit from fetal tissue transplantation research.

In addition to lifting the ban, Waxman's bill, entitled "Research Freedom Act of 1990 ", would establish a mechanism for the review and approval of experiments in biomedical and behavioural research. Once an experiment has been reviewed and recommended for approval by both an institutional review board and a peerreview group, National Institutes of Health (NIH) funding could be denied on ethical grounds only on the recommendation of an ethics advisory board (EAB) of legal, ethical, religious and scientific experts convened by the Secretary of Health.

Douglas Johnson, legislative director of the National Right to Life Committee, oppposes Waxman's initiative and says that it does much more than simply lift the ban. Under the proposed legislation, the secretary would be required to support any research approved by the EAB and, therefore, "would no longer have the final word", he says.

The ban was introduced temporarily in March 1988 by the then Assistant Secretary of Health Robert Windom after the NIH had sought his approval for an experiment involving the transplantation of human fetal cells into the brain of a patient with Parkinson's disease. Windom withheld approval pending the deliberations of an NIH panel set up to examine the ethical, legal and scientific implications of the experiment. The panel concluded that fetal tissue transplant research was "acceptable public policy" provided that certain safeguards were developed to prevent the commercialization of fetal tissue and to ensure that the decision to abort was made independently of the decision to donate fetal tissue to research.

Despite the panel's recommendations, Secretary of Health Louis Sullivan extended the ban indefinitely last November (see Nature 342, 105; 1989). He argued abortion. that women who are ambivalent about abortion may be influenced by the knowledge that the fetal tissue could be used to treat human disease, and concluded that the department should not be funding activities that encourage or promote

Curt Freed of the University of Colorado believes that the ban has considerably hampered research and adds that it is not just a question of money being available but also the "feeling that the government is not approving of this work and therefore maybe you shouldn't be doing it". Freed was the first US scientist to implant fetal neurons taken from the brain of a first-trimester aborted fetus into the brain of a patient with Parkinson's disease. The rationale was that fetal cells, which are thought to survive and integrate much better in the adult brain than transplants of more mature tissue, would produce dopamine, the chemical whose absence causes the uncontrolled tremors and muscle rigidity symptomatic of Parkinson's disease.

By contrast, Keith Crutcher, a neuroscientist at the University of Cincinnati who objects to most cases of induced abortion and who does not use human fetal tissue in his research, believes that "as scientists we cannot really divest ourselves from the need to look at the moral consequences of what we are doing".

Waxman's proposed legislation, which is supported by Ted Weiss (Democrat, New York) and Nancy Johnson (Republican, Connecticut), is urging disease associations to encourage 'grass-roots' support among its members. Although the administration is likely to veto the bill if it is passed by Congress, Waxman aide Tim Westmoreland says, "he [Bush] should at least have to face the Parkinson patients and the diabetics and tell them that he's vetoing it". The proposed legislation promises a heated debate. Diane Gershon

\title{
MITI envious of MIT
}

\section{Tokyo}

JAPAN's old habit of worrying just will not go away. Never mind that its economic miracle has made it the envy of the world, never mind that the Japanese live longer, never mind that their cities are the safest in the world, they still worry that they may be missing something. Now the Japanese have spotted that they do not have a worldclass international centre of academic excellence - a Massachusetts Institute of Technology (MIT) or a Max-Planck Institute. Having discovered what is missing, the Ministry of International Trade and Industry (MITI) and the Science and Technology Agency (STA) are now worrying what to do about it.

Unfortunately, MIT is not for sale (yet). But leading foreign academics might be. One suggestion is that Japan should set up a a new centre of excellence with some foreign staff, or a famous foreign director to give it class. (This is exactly what the Japanese did a little over a hundred years ago when they were setting up Tokyo University. Eventually many of the teachers were sent home - but while they were there their salaries were 3-4 times that of their Japanese colleagues.)

Concern over the missing centre of excellence first emerged back in 1988, in STA's annual white paper. Just to be sure that the concern was not unfounded, a survey followed. As predicted, it proved conclusively that most top Japanese academics have never sighted a centre of excellence in Japan (see Nature 344, 94; 1990). The absence of such a centre was immediately put forward as one explanation for the failure of young foreign scientists to flock to Japan to take up the various new postdoctoral fellowships that have been put on offer.

Now MITI has jumped on the bandwagon. In June the ministry said in its "Ten-year vision for the 1990s" that there is a need to establish a basic research centre to promote international research exchange and collaboration among industry, government and academic institutions. This was quickly followed by a proposal from MITI's Agency of Industrial Science and Technology (AIST) to convert some of the agency's institutes in Tsukuba into a centre of excellence. Last week the fad really took off when an advisory panel of academics and industrialists, the International High-Tech Technology Cooperation Committee, recommended to another section of the ministry, the Machinery and Information Industries Bureau, that Japan should establish such centres of excellence to try to redress the gross imbalance in the flow of researchers between Japan and the western world.

Katsuhiko Umehara of AIST says it is only a "very vague and abstract idea" at this stage but MITI will try "to harness the vitality of the private sector" (a Japanese expression meaning 'ask very politely for money'), perhaps by establishing a private foundation. The foundation would fund a new multidisciplinary research and development centre in Tsukuba. The institute would be open to foreign scientists and might even be headed by one. But Umehara says a foreign director is not an essential ingredient.

David Swinbanks 